\title{
PENGARUH TECHNOLOGY ACCEPTANCE MODEL (TAM) DAN TRUST TERHADAP INTENSI PENGGUNA INSTAGRAM
}

\author{
Erlangga Andi Sukma'); Musthofa Hadi $^{2)}$; Farika Nikmah ${ }^{3)}$ \\ erlangga.andis@gmail.com ${ }^{1)}$; cakmust2@gmail.com ${ }^{2)}$; farikanikmah@gmail.com
}

Jurusan Administrasi Niaga, Politeknik Negeri Malang, Malang, Indonesia

\section{Info Artikel}

Sejarah Artikel:

Diterima :juni 2019

Disetujui : Juli 2019

Dipublikasikan: Agustus

2019

Keywords:

Technology Acceptance Model; Perceived Ease Of Use; Perceived Usefulness; Trus; Intention to Use.

\begin{abstract}
Abstrak
Studi ini meneliti perilaku adopsi individu dari situs jejaring sosial paling populer saat ini Instagram. Pengaruh pada intensi terhadap penggunaan jejaring sosial berdasarkan persepsi kemudahan penggunaan individu (PEU), persepsi kemanfaatan (PU) dan kepercayaan secara empiris diperiksa dengan kumpulan data primer dari 95 mahasiswa Administrasi Bisnis di Politeknik Negeri Malang, pengguna Instagram dikumpulkan dari survei kuesioner. Hasil penelitian menunjukkan bahwa model TAM media sosial yang diusulkan dalam penelitian ini mendukung semua hipotesis intensi terhadap penggunaan media sosial. Hasil penelitian ini memberikan bukti untuk pentingnya variabel kunci tambahan untuk TAM dalam mempertimbangkan keterlibatan pengguna di situs media sosial dan strategi bisnis terkait media sosial lainnya.
\end{abstract}

\section{Abstract}

This study examines individual adoption behavior of the most popular social networking site Instagram. The influences on the intetion toward using social networkinf based on individual's perceived ease of use (PEU), perceived usefulness (PU) and trust is empirically examined with a primary data set of 95 students of Business Administration at State Polytechnic of Malang, users of Instagram gathered from a questionnaire survey. The results demonstrate that the revised social media TAM model proposed in this study supports all the hypotheses of intention toward using social medial. The results of this study provide evidence for the importance of additional key variables to TAM in considering user engagement on social media sites and other social-media related business strategies. 


\section{PENDAHULUAN}

Saat ini, satu fenomena yang berkembang di internet adalah media sosial yang tak dapat disangkal. Istilah media sosial telah tumbuh begitu populer di kalangan pengguna internet terutama dalam arti menjadi universal dan banyak digunakan. Media sosial telah berubah secara drastis seperti cara orang berkomunikasi dan kekuatan media sosial memungkinkan kita untuk tetap berhubungan dengan kejadian terbaru di seluruh dunia dalam beberapa menit atau bahkan jam dalam waktu nyata. Ini menjadi alat komunikasi global yang penting juga. Selain itu teknologi baru dan internet memungkinkan transfer data super cepat sehingga orang dapat berkomunikasi di seluruh dunia dan hanya membayar tarif lokal. Pada dasarnya media sosial adalah media online sebagai alat komunikasi sosial (Destiana dan Salman, 2015). Menurut kamus online Webster yang dikutip Rauniar et al. (2014), media sosial didefinisikan sebagai bentuk komunikasi elektronik (sebagai situs web untuk jejaring sosial dan microblogging) di mana pengguna membuat komunitas online untuk berbagi informasi, ide, pesan pribadi, dan lainnya (misalnya video).

Media sosial atau disebut juga dengan sosial media adalah media yang didesain untuk memudahkan interaksi sosial yang bersifat interaktif atau dua arah. Media sosial berbasis pada teknologi internet yang mengubah pola penyebaran informasi dari yang sebelumnya bersifat satu ke banyak audiens, banyak audiens ke banyak audiens (Paramitha, 2011).

Salah satu jenis media sosial adalah Instagram. Instagram merupakan media sosial yang hanya memiliki layanan pengunggahan gambar/ foto dan video untuk dipublikasikan. Instagram merupakan satu-satunya media online yang terlindungi dalam penyimpanan foto yang ada di dalamnya, sehingga menyulitkan pihak lain untuk melakukan penduplikasian.

Tidak semua teknologi yang tercipta dapat diterima, teknologi yang tercipta terkadang dapat diterima ataupun ditolak karena beberapa sebab. Penerimaan penggunaan dan penolakan teknologi dapat diprediksi menggunakan Technology Acceptance Model (TAM) yang pertama kali dikemukaan oleh Davis (1989), model ini memprediksi kemungkinan teknologi baru diadopsi dalam kelompok individu atau organisasi. TAM dibangun berdasarkan pendapat dari Fishbein dan Ajzen (1975) mengenai Theory of Reason Actioned (TRA). TRA berakar pada psikologi sosial dan mencoba untuk menjelaskan mengapa individu terlibat dalam perilaku yang dimaksudkan secara sadar.

Ada dua sebab orang menerima atau menolak aplikasi teknologi informasi, yakni pertama orang cenderung menggunakan atau tidak menggunakan teknologi informasi, karena mereka percaya bahwa teknologi informasi ini mampu membantu (mempersulit) dalam melakukan tugas-tugas dengan lebih baik, variabel ini disebut sebagai perceived usefulness (PU). Kedua, sekalipun pengguna potensial percaya bahwa sistem ini berguna, namun pada saat yang sama mereka juga mempercayai bahwa sistem ini terlalu sulit untuk digunakan, variabel ini disebut sebagai perceived ease of use (PEU). Para peneliti yang mengkaji sistem informasi telah menemukan bahwa perceived usefulness dan perceived ease of use memiliki pengaruh terhadap Intensi (Intentions) untuk menggunakan sistem teknologi informasi (Wida et al. 2016)

Menurut Alagoz dan Hekimoglu (2012), kepercayaan (Trust) membentuk dasar keyakinan konsumen tentang keamanan media online. Secara ringkas, dalam penelitian ini kami menyebutkan kepercayaan konsumen terhadap kualitas layanan pelanggan dan keandalan aplikasi media sosial. Kepercayaan merupakan faktor penting dalam lingkungan internet (Lai dan Li, 2005). 
Pentingnya mengkaji model penerimaan teknologi dalam mengukur perilaku konsumen penggunaan teknologi maka peneliti ingin menganalisa pengaruh Technology Acceptance Model (TAM) dan Trust terhadap Intensi Pengguna Instagram.

\section{TELAAH PUSTAKA}

\section{Technology Acceptance Model (TAM)}

TAM dikembangkan oleh Davis (1989) untuk mengemukakan teori perilaku penggunaan teknologi komputer. TAM diadopsi dari teori populer yaitu Theory of Reason Actioned (TRA) Fishbein dan Ajzen (1975) dari bidang psikologi sosial yang menjelaskan perilaku seseorang melalui niat mereka. Niat (intention) pada gilirannya ditentukan oleh dua konstruk: Intensi individu terhadap perilaku dan norma sosial atau keyakinan bahwa individu tertentu atau kelompok tertentu akan menyetujui atau menyangkal perilaku tersebut. Sementara TRA berteori untuk menjelaskan perilaku manusia secara umum, TAM secara khusus menjelaskan faktor penentu penerimaan komputer yang umum dan mampu menjelaskan perilaku pengguna di berbagai teknologi komputasi pengguna akhir dan populasi pengguna (Rauniar et al., 2013).

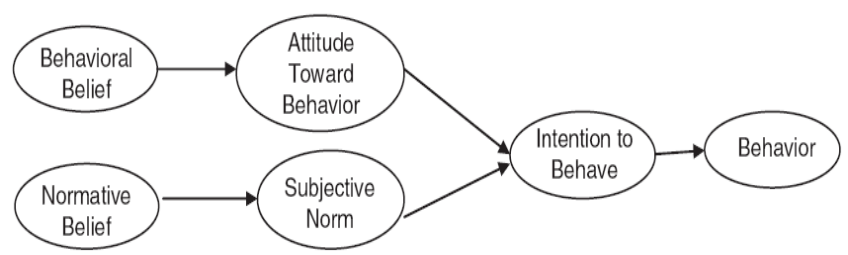

Gambar 1.

Theory of Reason Actioned (TRA)

Sumber: Fishbein dan Ajzen (1975)

Technology Acceptance Model (TAM) adalah suatu model untuk memprediksi dan menjelaskan bagaimana pengguna teknologi menerima dan menggunakan teknologi yang berkaitan dengan pekerjaan pengguna. Model TAM berasal dari teori psikologis untuk menjelaskan perilaku pengguna teknologi informasi yang berlandaskan pada kepercayaan (belief), Intensi (Intention), niat (intention) dan hubungan perilaku pengguna (user behavior relationship). Teori ini membuat model perilaku seseorang sebagai suatu fungsi dari tujuan perilaku.

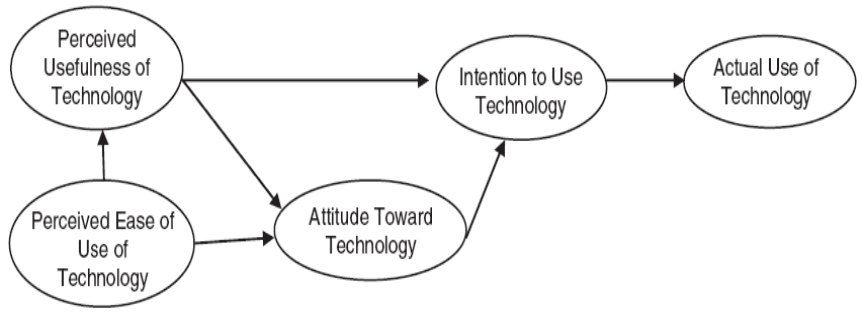

Gambar 2.

Technology Acceptance Model (TAM)

Sumber: Davis (1986) 


\section{Intensi (Intention)}

Intensi merupakan suatu niat atau keinginan individu untuk melakukan perilaku tertentu (Dayakisni \& Hudaniah, 2015). Selain itu, menurut Ajzen (2005), intensi dapat dijelaskan melalui teori perilaku terencana yang merupakan pengembang-an dari teori tindakan beralasan. Intensi merefleksikan kesedian individu untuk mencoba melakukan suatu perilaku tertentu (Ajzen, 2005).

Dalam referensi lainnya, Ajzen dalam Teo \& Lee (2010), mengemukakan definisi intensi yaitu indikasi seberapa kuat keyakinan seseorang akan mencoba suatu perilaku, dan seberapa besar usaha yang akan digunakan untuk melakukan sebuah perilaku. Intensi memiliki korelasi yang tinggi dengan perilaku, oleh karena itu dapat digunakan untuk meramalkan perilaku (Ajzen, 2005).

\section{Perceived Ease of Use (PEU)}

Jaringan media sosial menyediakan berbagai peluang di antaranya memungkinkan komunikasi, kolaborasi, berbagi informasi dan kesenangan yang semuanya disarankan sebagai faktor penting yang mempengaruhi adopsi Instagram. Perceived Ease of Use telah didefinisikan sebagai "sejauh mana seseorang percaya bahwa menggunakan sistem tertentu akan bebas dari usaha" (Venktatesh dan Davis, 2000).

Meningkatnya keragaman orang yang mendaftar dengan media sosial menunjukkan bahwa itu harus relatif mudah untuk membuat akun dan mulai menggunakan dan menikmati layanan. Rauniar et al., (2014) mendefinisikan Perceived Ease of Use sebagai derajat di mana situs media sosial bebas dari upaya.

\section{Perceived Usefulness (PU)}

Faktor penting yang mempengaruhi adopsi jaringan media sosial adalah kombinasi dari keterampilan teknis pengguna tertentu dan kompetensinya dalam fitur-fitur khusus Instagram. Perceived Usefulness didefinisikan sebagai "sejauh mana seseorang percaya bahwa menggunakan sistem tertentu akan meningkatkan kinerja pekerjaannya" (Venktatesh dan Davis, 2000).

Dalam penelitian Rauniar et al., (2014) mendefinisikan Perceived Usefulness sebagai sejauh mana pengguna media sosial percaya bahwa menggunakan situs media sosial tertentu membantu memenuhi kebutuhan-kebutuhan individu yang digerakkan oleh tujuan. Setiap aplikasi media sosial menawarkan layanan utama tertentu, dan oleh karena itu menawarkan berbagai jenis alat dan aplikasi untuk menambah nilai utilitarian bagi audiensinya.

\section{Trust}

Sejauh mana pengguna yakin kontrak implisit dengan situs media sosial dan pengguna lain sangat penting dalam memahami aktivitas dan perilaku pengguna termasuk pertukaran informasi secara sukarela. Oleh karena itu, Rauniar et al., (2014) percaya bahwa masalah kepercayaan (trust) dari situs media sosial merupakan konstruksi penting untuk model TAM untuk media sosial.

Menurut Mayer et al. yang dikutip oleh Tripathi (2014) kepercayaan (trust) mencerminkan kepercayaan individu bahwa informasi pribadi yang dikirimkan ke SNS (Social Networking Sites) akan ditangani dengan kompeten, penuh kebaikan, dan dengan integritas oleh SNS. Menurut Alagoz dan Hekimoglu (2012), kepercayaan (Trust) membentuk dasar keyakinan konsumen tentang keamanan media online. 
Maka situs media sosial dapat menggunakan berbagai tingkat fitur keamanan untuk mengurangi masalah privasi pengguna, dan membangun kepercayaan (Culnan dan Armstrong, 1999)

\section{METODE}

\section{Desain Penelitian}

Pendekatan yang akan dilakukan adalah penelitian survey, dengan menggunakan analisis data kuantitatif dan kualitatif.

\section{Subyek Penelitian}

Subyek yang digunakan dalam penelitian ini adalah semua mahasiswa pengguna aplikasi media sosial Instagram di Jurusan Administrasi Niaga Politeknik Negeri Malang, yang jumlahnya sulit diketahui karena belum ada rekapan data yang pasti. Menurut Ferdinand (2014:173) ada beberapa cara menghitung atau menentukan jumlah sampel yang baik dapat ditentukan dengan cara sebagai berikut:

Sampel $(n)=19$ pertanyaan/item $x 5=95$ responden .

\section{Lokasi Penelitian}

Penelitian dilaksanakan di Jurusan Administrasi Niaga Politeknik Negeri Malang Jalan Soekarno-Hatta No. 9 Kota Malang.

\section{Jenis data dan Prosedur Penelitian}

Ada beberapa jenis data yang akan dikumpulkan dalam strategi peng-embangan penelitian dan sekaligus metode pengumpulan datanya sebagai berikut; (1) Data berasal dari responden yang dipilih berdasarkan pertimbangan tertentu pada mahasiswa Jurusan Administrasi Niaga Politeknik Negeri Malang pengguna Instagram dengan menjawab pertanyaan-pertanyaan yang ditulis dalam kuesioner; (2) Dalam penelitian ini data sekunder berupa dokumen tempat penelitian yang ada di Jurusan Administrasi Niaga Politeknik Negeri Malang.

\section{Teknik Pengumpulan Data}

1. Panduan interview dan observasi, untuk melaksanakan identifikasi pengguna aplikasi Instagram dalam memilih model TAM.

2. Seperangkat angket untuk survey atau penjaringan konsumen, sebagai subyek penelitian.

\section{Teknik Analisis Data}

Metode penelitian kuantitatif dapat diartikan sebagai metode penelitian yang berlandaskan pada filsafat positifisme, digunakan untuk meneliti pada populasi atau sampel tertentu, pengumpulan data menggunakan instrument penelitian, analisis data bersifat kuantitati atau statistik. Dengan tujuan untuk menguji hipotesis yang telah ditetapkan. (Sugiyono, 2014: 8). Urutan analisis yang dilakukan dalam penelitian ini adalah sebagai berikut: (1)Uji validitas dan reliabilitas; (2) Analisis regresi linier berganda; (3) Analisis determinan dan (4) Uji hipotesis 


\section{HASIL DAN PEMBAHASAN}

\section{Uji Validitas}

Berdasarkan uji validitas, menunjukkan bahwa keseluruhan item yang digunakan sebagai alat ukur variabel PEU $\left(\mathrm{X}_{1}\right)$, PU $\left(\mathrm{X}_{2}\right)$, Trust $\left(\mathrm{X}_{3}\right)$, dan variabel Intensi (Y) adalah valid. Hal ini dapat dilihat dari nilai $r$ hitung $>$ nilai $r$ tabel $(0,201)$. Valid berarti item-item dalam variabel PEU $\left(\mathrm{X}_{1}\right)$, PU $\left(\mathrm{X}_{2}\right)$, Trust $\left(\mathrm{X}_{3}\right)$ dan variabel Intensi (Y) dapat mengukur seberapa kuat atau lemah pengaruh PEU, PU dan Trust terhadap Intensi pada mahasiswa Jurusan Administrasi Niaga Politeknik Negeri Malang pengguna aplikasi Instagram.

\section{Uji Reliabilitas}

Berdasarkan tabel uji reliabilitas menunjukkan bahwa keseluruhan item yang digunakan sebagai alat ukur PEU $\left(\mathrm{X}_{1}\right)$, PU $\left(\mathrm{X}_{2}\right)$, Trust $\left(\mathrm{X}_{3}\right)$ dan variabel Intensi (Y) adalah reliabel atau konsisten.Hal ini dapat dilihat dari nilai cronbach's alpha dengan nilai standart $\geq 0,60$, maka dapat dijelaskan bahwa item-item dalam penelitian ini reliabel atau konsisten. Pada variabel faktor PEU $\left(\mathrm{X}_{1}\right)$ nilai cronbach's alpha $\geq 0,60$ adalah 0,885 , variabel $\mathrm{PU}\left(\mathrm{X}_{2}\right)$ nilai cronbach's alpha $\geq 0,60$ adalah 0,719 , variabel faktor Trust $\left(\mathrm{X}_{3}\right)$ nilai cronbach's alpha $\geq$ 0,60 adalah 0,858, sedangkan variabel Intensi Penggunaan (Y) nilai cronbach's alpha $\geq$ 0,60 adalah 0,764 . Sehingga dapat dinyatakan bahwa semua item pernyataan tersebut reliabel, artinya keseluruhan item yang digunakan dalam penelitian pengaruh PEU, PU dan Trust terhadap Intensi Penggunaan Media Sosial pada mahasiswa Jurusan Administrasi Niaga Politeknik Negeri Malang pengguna aplikasi Instagram hasilnya akan tetap sama jika diuji pada penelitian selanjutnya, atau keseluruhan item yang diteliti hasilnya konsisten.

\section{Regresi Linear Berganda}

Setelah dilakukan uji menggunakan program SPSS 20 for windows, maka hasil dari regresi linear berganda didapat hasil perumusan sebagai berikut :

\section{$Y=7,313+(-) 0,007 X_{1}+0,492 X_{2}+0,165 X_{3}$}

Berdasarkan persamaan diatas dapat ditarik kesimpulan sebagai berikut :

a. Konstanta $\mathrm{a}=7,313$

Artinya apabila variabel bebas yang terdiri dari PEU $\left(\mathrm{X}_{1}\right), \mathrm{PU}\left(\mathrm{X}_{2}\right)$, Trust $\left(\mathrm{X}_{3}\right)$ diabaikan atau bernilai nol (konstan), maka Intensi Penggunaan nilainya sebesar 7,313.

b. Koefesien Regresi Variabel PEU $\left(\mathrm{X}_{1}\right)$ sebesar - 0,007.

Jika variabel PEU $\left(\mathrm{X}_{1}\right)$ mengalami kenaikan 1\%, maka terhadap Intensi (Y) akan mengalami penurunan 0,007 kali dengan asumsi variabel independen lain nilainya tetap. Koefisien bernilai negatif artinya terjadi hubungan yang negatif antara variabel PEU dan variabel Intensi. Variabel PEU media sosial Instagram dapat menurunkan Intention to use (Intensi penggunaan) dalam penggunaan media sosial di kalangan mahasiswa Jurusan Administrasi Niaga Politeknik Negeri Malang karena terbukti adanya pengaruh.

c. Koefesien Regresi Variabel PU $\left(\mathrm{X}_{2}\right)$ sebesar 0,492.

Artinya jika variabel PU $\left(\mathrm{X}_{2}\right)$ mengalami kenaikan $1 \%$, maka terhadap Intensi $(\mathrm{Y})$ akan mengalami peningkatan 0,492 kali dengan asumsi variabel independen lain nilainya tetap. Koefisien bernilai positif artinya terjadi hubungan yang positif antara variabel PU dan variabel Intensi. Artinya variabel PU media sosial instagram dapat meningkatkan Intention to use (Intensi penggunaan) dalam penggunaan media sosial di kalangan mahasiswa Jurusan Administrasi Niaga Politeknik Negeri Malang karena terbukti adanya pengaruh.

d. Koefesien Regresi Variabel Trust $\left(\mathrm{X}_{3}\right)$ sebesar 0,165. 
Jika variabel Trust $\left(\mathrm{X}_{3}\right)$ mengalami kenaikan 1\%, maka terhadap Intensi (Y) akan mengalami peningkatan 0,1655 kali dengan asumsi variabel independen lain nilainya tetap. Koefisien bernilai positif artinya terjadi hubungan yang positif antara variabel Trust dan variabel Intensi. Artinya variabel Trust media sosial instagram dapat meningkatkan Intention to use (Intensi penggunaan) dalam penggunaan media sosial di kalangan mahasiswa Jurusan Administrasi Niaga Politeknik Negeri Malang karena terbukti adanya pengaruh.

\section{Nilai Koefisien Determinasi $\left(\mathbf{R}^{2}\right)$}

Dari hasil perhitungan analisis regresi linier berganda yang telah dilakukan menunjukkan kemampuan model dalam pengaruh variabel independen (variabel PEU, PU dan Trust) terhadap variabel dependen (Intensi Penggunaan) adalah cukup besar, hal tersebut dapat dilihat pada nilai Adj. $R$. Square $\left(R^{2}\right)$ yaitu sebesar 0,225. Dengan demikian berarti bahwa model regresi yang digunakan mampu menjelaskan pengaruh variabel PEU, PU dan Intensi terhadap pengguna aplikasi Instagram sebesar 22,5\%, sedangkan sisanya sebesar $(100 \%-22,5 \%=77,5 \%)$ di jelaskan oleh variabel lain yang tidak diteliti dalam penelitian ini.

Berdasarkan hasil analisis regresi linier berganda dari masing - masing variabel faktor PEU, PU dan Trust menunjukkan bahwa adanya korelasi berganda ( $\mathrm{r}$ ) sebesar 0,500. Angka tersebut menunjukkan adanya hubungan yang cukup kuat antara variabel bebas yaitu PEU, PU dan Trust terhadap variabel terikat yaitu Intensi Penggunaan.

\section{Pembahasan Hasil Penelitian}

Penelitian yang melibatkan 95 responden, memberikan informasi mengenai pengaruh dari variabel PEU, PU dan Trust terhadap Intensi mahasiswa pengguna aplikasi media sosial Instagram. Berdasarkan uji validitas dapat diketahui bahwa semua item pernyataan PEU, PU, Trust, dan Intensi mempunyai nilai pearson correlation dari $r_{\text {tabel }}(>0,201)$. Sehingga dapat diketahui bahwa semua item pernyataan untuk semua variabel tersebut dinyatakan valid.

Berdasarkan hasil uji realibilitas dapat diketahui bahwa beberapa item pernyataan dari variabel PEU, PU, Trust, dan Intensi mempunyai cronbach's alpha dengan nilai $\geq 0,60$; maka dapat dijelaskan bahwa item-item dalam penelitian ini reliabel atau konsisten. Sehingga dapat dinyatakan bahwa semua item pernyataan tersebut reliabel, artinya keseluruhan item yang digunakan dalam penelitian pengaruh PEU, PU dan Trust terhadap Intensi pada mahasiswa Jurusan Administrasi Niaga Politeknik Negeri Malang pengguna aplikasi Instagram hasilnya akan tetap sama jika diuji pada penelitian selanjutnya, atau keseluruhan item yang diteliti hasilnya konsisten.

\section{Pengaruh PEU, PU dan Trust terhadap Intensi Berpengaruh Secara Bersama-Sama (Simultan)}

Secara simultan berpengaruh positif dan signifikan antara variabel faktor PEU, PU dan Trust terhadap Intensi. Dari uji $\mathrm{F}_{\text {hitung }}$ menunjukkan bahwa variabel independen yang digunakan dalam penelitian ini adalah variabel PEU, PU dan Trust adalah layak untuk menguji variabel dependen, yaitu Intensi Penggunaan. Hal tersebut menunjukkan dari besarnya nilai $\mathrm{F}_{\text {hitung }}$ yang lebih besar dari nilai $\mathrm{F}_{\text {tabel }}$ yaitu $10,084>2,70$ maka $\mathrm{H}_{0}$ ditolak dan $\mathrm{H}_{\mathrm{a}}$ yang diterima yang artinya bahwa variabel PEU $\left(\mathrm{X}_{1}\right), \mathrm{PU}\left(\mathrm{X}_{2}\right)$ dan Trust $\left(\mathrm{X}_{3}\right)$ secara bersama-sama mempunyai pengaruh positif dan signifikan terhadap Intensi (Y). 
Dengan hal ini sesuai dengan penelitian yaitu hipotesis yang pertama menyatakan bahwa variabel PEU $\left(\mathrm{X}_{1}\right)$, PU $\left(\mathrm{X}_{2}\right)$ dan Trust $\left(\mathrm{X}_{3}\right)$ secara bersama-sama mempunyai pengaruh terhadap Intensi Penggunaan (Y).

Hasil penelitian ini sesuai dengan hasil kajian penelitian terdahulu yang diteliti oleh Alagoz dan Hekimoglu (2012) serta Munoz-Leiva et al. (2017).

\section{Pengaruh Perceived Ease of Use (PEU) terhadap Intensi Berpengaruh Secara Parsial}

Secara parsial variabel PEU tidak memiliki pengaruh terhadap Intensi. Dengan nilai signifikan lebih kecil dari nilai probabilitas yaitu 0,05 atau $0,938>0,05$, maka $\mathrm{H}_{0}$ diterima dan $\mathrm{H}_{\mathrm{a}}$ ditolak. Variabel PEU mempunyai $\mathrm{t}_{\text {hitung }}$ sebesar $-0,078<\mathrm{t}_{\text {tabel }} 1,66177$. Jadi dapat disimpulkan PEU $\mathrm{H}_{0}$ diterima yang artinya $\mathrm{PEU}\left(\mathrm{X}_{1}\right)$ secara parsial tidak memiliki pengaruh terhadap Intensi Penggunaan.

Hal ini tidak sesuai dengan penelitian pada hipotesis kedua yang menyatakan bahwa variabel PEU $\left(\mathrm{X}_{1}\right)$ berpengaruh secara parsial terhadap Intensi $(\mathrm{Y})$. Hasil penelitian ini tidak sesuai dengan hasil kajian penelitian terdahulu yang diteliti oleh Wida et al. (2016) dan Phuong dan Vinh (2017) yang menyatakan bahwa variabel PEU berpengaruh signifikan terhadap Intensi Penggunaan.

Temuan penelitian ini juga mendukung pendapat Aslam et al. (2017) sejauh menyangkut kemudahan penggunaan (PEU), tampaknya konsumen menganggapnya tidak penting, sehingga tidak lagi menjadi variabel yang signifikan dalam proses Intensi untuk mengadopsi penggunaan teknologi ini. Namun, penyedia layanan ini harus dengan segala cara berusaha untuk membuat mereka ramah pengguna dan mudah digunakan.

\section{Pengaruh Perceived Usefullnes (PU) terhadap Intensi Berpengaruh Secara Parsial}

Secara parsial terdapat pengaruh yang signifikan dari variabel PU terhadap Intention. Nilai signifikan lebih besar dari nilai probabilitas yaitu 0,05 atau $0,000<0,000$, maka $\mathrm{H}_{\mathrm{a}}$ diterima dan $\mathrm{H}_{0}$ ditolak. Variabel PU mempunyai $t_{\text {hitung }}$ sebesar 4,149 $>\mathrm{t}_{\text {tabel }} 1$,66177. Jadi dapat disimpulkan $\mathrm{PU}\left(\mathrm{X}_{2}\right)$ Ha diterima yang artinya $\mathrm{PU}\left(\mathrm{X}_{2}\right)$ secara parsial berpengaruh terhadap Intensi sebesar 0,492.

Hal ini sesuai dengan penelitian pada hipotesis ketiga yang menyatakan bahwa variabel PU $\left(\mathrm{X}_{2}\right)$ berpengaruh secara parsial terhadap Intensi $(\mathrm{Y})$. Hasil penelitian ini sejalan dengan hasil kajian penelitian terdahulu yang diteliti oleh Wida et al. (2016) dan Phuong dan Vinh (2017).

Temuan penelitian ini juga mendukung pendapat Davis (1989) dalam menciptakan unsur-unsur kegunaan yang dirasakan (PU) dalam mempengaruhi Intensi penggunaan aplikasi teknologi. Ini adalah sejauh mana pengguna percaya bahwa menggunakan sistem akan meningkatkan kinerja pekerjaan mereka, dalam proses yang tidak merepotkan. Jika ya, maka seseorang akan berkomitmen untuk menggunakan aplikasi tersebut.

\section{Pengaruh Trust terhadap Intensi Berpengaruh Secara Parsial}

Secara parsial terdapat pengaruh yang signifikan dari variabel Trust terhadap Intensi. Nilai signifikan lebih besar dari nilai probabilitas yaitu 0,05 atau 0,103>0,05, maka $\mathrm{H}_{0}$ diterima dan $\mathrm{H}_{\mathrm{a}}$ ditolak. Variabel Trust mempunyai $\mathrm{t}_{\text {hitung }}$ sebesar 1,646 $>\mathrm{t}_{\text {tabel }}$ 1,66177. Jadi dapat disimpulkan Trust $\left(\mathrm{X}_{3}\right) \mathrm{H}_{0}$ diterima yang artinya Trust $\left(\mathrm{X}_{3}\right)$ secara parsial tidak berpengaruh terhadap Intensi. 
Hasil penelitian ini tidak sesuai dengan hasil kajian penelitian terdahulu yang diteliti oleh Alagoz dan Hekimoglu (2012) serta Munoz-Leiva et al. (2017). Temuan penelitian ini mendukung kajian penelitian terdahulu Kusyanti et al. (2018) yang dapat disimpulkan bahwa responden berpikir bahwa media sosial tidak menjamin keamanan profil mereka dan posisi mereka di media sosial karena itu mempengaruhi intensi mereka untuk menggunakan media sosial Instagram.

\section{PENUTUP}

Berdasarkan hasil uji $\mathrm{F}$ pada penelitian ini secara simultan berpengaruh positif dan signifikan antara variabel PEU, PU dan Trust terhadap Intensi penggunaan aplikasi Instagram. Jadi hubungan antara ketiga variabel yaitu variabel PEU, variabel PU dan variabel Trust sangat berpengaruh terhadap Intensi penggunaan aplikasi Instagram.

Berdasarkan hasil uji t secara parsial hanya variabel PU yang memiliki pengaruh secara parsial terhadap Intensi penggunaan aplikasi Instagram. Sedangkan variabel PEU dan Trust tidak ditemukan pengaruh yang signifikan terhadap Intensi dalam penggunaan aplikasi Instagram.

Lalu dari perhitungan koefesien regresi linear berganda bahwa hasil yang tertinggi dan yang berkontribusi terhadap variabel Intensi adalah Variabel Perceived Usefulness PU $\left(\mathrm{X}_{2}\right)$. Hal ini menunjukkan bahwa antara variabel PEU, variabel PU dan variabel Trust, variabel Perceived Usefulness (PU) yang memiliki peran atau yang berpengaruh secara dominan terhadap Intensi dalam penggunaan aplikasi Instagram.

\section{DAFTAR PUSTAKA}

Ajzen, Icek. 2005. Attitudes, Personality, and Behavior. New York : Open University Press.

Alagoz, Serhat Murat dan Haluk Hekimoglu. 2012. A Study on TAM: Analysis of Customer Intentions in Online Food Ordering System. Journal of Procedia - Social and Behavioral Sciences. Vol 62 (2012) 1138 - 1143. Elsevier.

Aslam, Wajeeha, Marija Ham, Imtiaz Arif. 2017. Consumer Behavioral Intentions Towards Mobile Payment Services: An Empirical Analysis In Pakistan. Journal of Market Economics and Business. Vol. 29 No. 2 (2017) pp. 161-176.

Davis, Fred D. 1989. Perceived Usefulness, Perceived Ease of Use, and User Acceptance of Information Technology. Journal of MIS Quarterly. Vol. 13 No. 3 (1989), pp. 319-340.

Dayakisni, Tri, dan Hudaniah. (2015). Psikologi Sosial. Malang: UMM Press

Destiana, Ika dan Ali Salman. 2015. The Acceptance, Usage and Impact of Social Media Among University Students. Journal of Social Sciences and Humanities. Issue 1 (2015) pp 058 - 065.

Ferdinand, Augusty. 2014. Metode Penelitian Manajemen. Edisi Kedua: Universitas Diponegoro. Semarang.

Fishbein, Martin dan Icek Ajzen. 1975. Belief, Intention, Intention and Behavior: An Introduction to Theory and Research. Addison-Wesley. Reading, MA.

Kusyanti, Ari., Harin Puspa Ayu Catherina, Dita Rahma Puspitasari, Yustiyana April Lia Sari. 2018. Teen's Media Social Adoption: An Empirical Investigation in Indonesia. International Journal of Advanced Computer Science and Applications(IJACSA). Vol 9. No. 2 (2018). pp. 280-384. 
Lai, Vincent. S, dan Honglei Li. 2005. Technology Acceptance Model For Internet Banking: an Invariante Analysis. International Journal of Information \& Management. Vol 42 Iss 2 (2005), pp 373-386. Elsevier.

Munoz-Leiva, Francisco, S. Climent-Climent, Francisco Liébana-Cabanillas. 2017. Determinants of Intention To Use The Mobile Banking Apps: An Extension of The Classic TAM Model. Spanish Journal of Marketing - ESIC. Vol 21 (2017), 25-38. Elsevier.

Paramitha, Cindy Rizal Putri. 2011. Analisis Faktor Pengaruh Promosi Berbasis Sosial Media Terhadap Keputusan Pembelian Pelanggan dalam Bidang Kuliner. Thesis. Fakultas Ekonomi UNDIP. Semarang.

Phuong, Tran Thi Kim dan Tran Trung Vinh. 2017. Proposing an Extension of the Technology Acceptance Model to Explain Facebook User Acceptance of Facebook Event Page. Journal Asian Social Science. Vol. 13, No. 6 (2017) pp 133-141.

Rauniar, Rupak, Greg Rawski, Jei Yang, Ben Johnson. 2014. Technology Acceptance Model (TAM) and Social Media Usage: an Empirical Study on Facebook. Journal of Enterprise Information Management. Vol 27 Iss 1 pp. 6 - 30. Emerald Insight.

Selwendri dan Rumyeni. 2017. Implementasi Technology Acceptance Model Dalam Aktivitas Belanja Online Melalui Media Sosial Instagram Di Kalangan Mahasiswa Universitas Sumatera Utara. Jurnal Aplikasi Bisnis. Vol 7 No 1 (2017). https://ejournal.unri.ac.id.

Sugiyono. 2014. Metode Penelitian Kuantitatif, Kualitatif dan $R \& D$. CV Alfabeta. Bandung.

Teo, Timothy and Chwee Beng Lee. 2010. Explaining the Intention to Use Technology among Student Teachers: An application of th Theory of Planned Behavior (TPB). Campus-Wide Information Systems, Vol. 27, No. 2, 2010, pp. 60-67.

Tripathi, Shailja. 2014. Factors Influencing the Technology Acceptance of Social Media in India: A Literature Review and Research Agenda for Future. Journal of Advances in Computer Science and Information Technology (ACSIT). Vol 1 No 2 (2014) pp. 43-47.

Venktatesh, Viswanath. and Fred D. Davis. 2000. A Theoretical Extension Of The Technology Acceptance Model: Four Longitudinal Field Studies. Journal Management Science. Vol. 46 No. 2 (2000), pp. 186-204.

Wida, Putu Ayu Mira Witriyanti, Ni Nyoman Kerti Yasa dan I Putu Gde Sukaatmadja. 2016. Aplikasi Model TAM (Technology Acceptance Model) pada Perilaku Pengguna Instagram. Jurnal Ilmu Manajemen (JUIMA). Vol 6 No 2 (2016). http://ojs.unmas.ac.id. 